\title{
Long-term follow-up results of patients diagnosed with nonspecific pleuritis by video-assisted thoracoscopic surgery biopsy
}

Meltem Agca ${ }^{1}$, Reyhan Yildiz' ${ }^{1}$ Fatma T. Akyil ${ }^{2}$, Aycim Sen ${ }^{3}$, Aysun Kosif ${ }^{4}$, Mustafa Akyil ${ }^{5}$, Tulin Sevim ${ }^{1}$

\begin{abstract}
1Department of Pulmonology, University of Health Sciences Sureyyapasa Chest Diseases and Thoracic Surgery Training and Research Hospital, Istanbul, Turkey 2Department of Pulmonology, Canakkale State Hospital, Canakkale, Turkey

${ }^{3}$ Department of Pathology, University of Health Sciences Sureyyapasa Chest Diseases and Thoracic Surgery Training and Research Hospital, Istanbul, Turkey

${ }^{4}$ Department of Thoracic Surgery, University of Health Sciences Sureyyapasa Chest Diseases and Thoracic Surgery Training and Research Hospital, Istanbul, Turkey

${ }^{5}$ Department of Thoracic Surgery, Canakkale State Hospital, Canakkale, Turkey
\end{abstract}

Submitted: 9 June 2020

Accepted: 19 September 2020

Arch Med Sci

DOI: https://doi.org/10.5114/aoms.2020.100209

Copyright $\odot 2020$ Termedia \& Banach

\section{Abstract}

Introduction: Non-specific pleuritis (NSP) is a fibrinous or inflammatory pleurisy that is not attributable to a benign or malign etiology. The longterm follow-up results of patients diagnosed with NSP following videoassisted thoracoscopic surgery (VATS) were investigated in this study.

Material and methods: This investigation focused on 593 patients with exudative pleural effusion who underwent VATS between 2011 and 2014. Of the 137 patients diagnosed with NSP, a total of 39 patients were excluded from the study.

Results: Out of the 98 patients, 78 were male (80\%) with their mean age being $52.2 \pm 15.9$ years. The mean follow-up period was $1919 \pm 744$ days. Of these patients, $70(71.4 \%)$ had no specific diagnosis, while 28 patients $(28.6 \%)$ did have specific diagnoses. Malignancy was detected in seven $(7.1 \%)$ of those with specific diagnoses, with most of the diagnoses of malignancy detected within the first 36 months. Malignant diseases included mesothelioma $(n=2)$, lung cancer $(n=2)$, chronic lymphocytic leukemia $(n=1)$, soft tissue sarcoma $(n=1)$, and multiple myeloma $(n=1)$. Chest radiographs of malignant patients showed that statistically significantly larger amounts of fluid ( $40 \%$ vs. $6.9 \%$, $p=0.026)$, pleural plaque ( $20 \%$ vs. $1.1 \%, p=0.020)$ and nodules $(20 \%$ vs. $7.7 \%$, $\mathrm{p}=0.020$ ) were detected compared to patients with a benign course.

Conclusions: Most patients diagnosed with NSP after VATS had a benign disease course. There was a probability of malignancy, although it was low. Mesothelioma and other malignancies could be seen within the first 36 months after the biopsy. Apart from mesothelioma, other malignancies should also be considered, and further follow-up recommended for patients with a large amount of fluid, plaque and nodules found in the initial VATS images.

Key words: pleural effusion, non-specific pleuritis (NSP), video-assisted thoracoscopic surgery (VATS).

\section{Introduction}

Pleural effusion is a common medical problem that can be triggered by more than 50 known causes. It is estimated that only five diseases account for $90 \%$ of the cases, namely congestive heart failure, pneu-

\author{
Corresponding author: \\ Meltem Agca \\ Department of Pulmonology \\ University of Health Sciences \\ Sureyyapasa Chest Diseases \\ and Thoracic Surgery Training \\ Hospital \\ Istanbul, Turkey \\ E-mail: agcameltem@yahoo. \\ com
}


monia, malignancy, pulmonary embolism, and viral infections [1-3]. In 15-20\% of patients, benign or malign specific diagnosis cannot be made through examination of the detailed history of the patient, physical examination, radiological and laboratory parameters, or pleural fluid examinations, including closed pleural biopsy $[1,4,5]$.

The first step in the diagnosis of pleural effusions is thoracentesis, which can be diagnostic in approximately $50 \%$ of the patients [1]. Diagnostic thoracoscopic pleural biopsy is the gold standard for diagnosis [6], while biopsy via video-assisted thoracoscopic surgery (VATS) reaches a diagnosis rate over $95 \%$ in lung diseases and pleural effusions [7-9]. However, in rare cases a final diagnosis cannot be made via VATS biopsy, and they are considered to be idiopathic $[1,10]$. In the literature, this condition is referred to as "non-specific pleuritis" (NSP), "idiopathic pleurisy", "fibrinous pleurisy", or "pleurisy of indeterminate cause" [11]. Conditions that may cause significant mortality and morbidity, including primary malignancies as well as pulmonary embolism, and connective tissue disorders may develop during the follow-up of patients diagnosed with NSP $[1,11]$ and management of these patients may prove challenging for clinicians. In the present study, the clinical characteristics and long-term follow-up results of patients with NSP were investigated.

\section{Material and methods}

This study was a retrospective, single-center study designed in a training and research center for chest diseases. The study protocol was approved by the hospital's local scientific committee and was carried out in accordance with the Declaration of Helsinki.

\section{Study population}

Between January 2011 and December 2014, 593 patients with exudative pleural effusion who had undergone diagnostic VATS were evaluated. The study included 137 patients with a VATS histopathological diagnosis of NSP. Of the patients studied, a total of 39 patients were excluded. Among these patients, 15 cases were parapneumonic effusion, 8 cases were paramalignant syndrome, 10 cases were pachypleuritis and in one case the patient died on the postoperative $11^{\text {th }}$ day. Moreover, 5 cases were excluded due to unavailability of medical records. Ninety-eight patients with acute and chronic inflammation, non-specific inflammation, fibrosis, and those with no specific diagnoses via VATS biopsy were included in the study (Figure 1).

Patient demographics, smoking status, presentation symptoms, comorbidities, baseline laboratory values, and the radiological amount of pleural effusion found were included. The appearance of biochemical parameters in the pleural fluid samples taken by thoracentesis including glucose, protein, albumin, lactate dehydrogenase (LDH), adenosine deaminase (ADA), as well as microbiological examinations, total white cell count and differential cellular parameters (lymphocytic, neutrophilic, mixed, eosinophilic) were recorded from their medical files. Preoperative pleural fluid cytology results, additional radiological examinations and diagnostic procedures were also examined. The pleural images taken during VATS were then

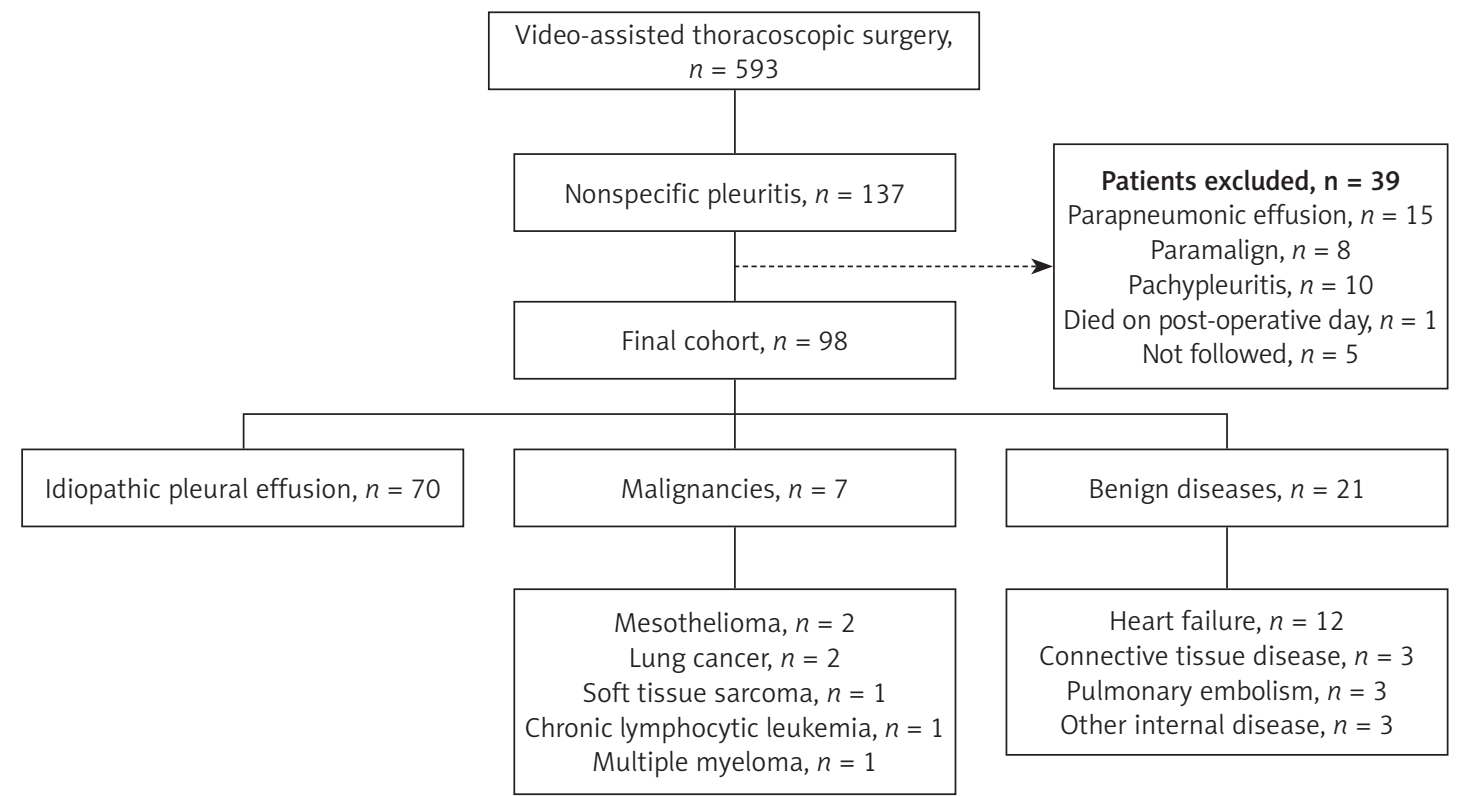

Figure 1. Flowchart of the study 
obtained from surgery notes (these consisted of normal, pleural nodules, pleural plaques, pleural thickening).

\section{Definitions}

Exudative fluid: This was performed according to the Light criteria: pleural fluid protein/serum protein $>0.5$, or pleural fluid $\mathrm{LDH} /$ serum $\mathrm{LDH}>0.6$, or pleural fluid $L D H>$ serum LDH 2/3 of the upper limit of the laboratory normal value [2].

Pleural fluid volume: Small meaning less than $1 / 3$ of a hemithorax; moderate fluid, meaning more than $1 / 3$ but less than half of a hemithorax; and large meaning more than half of a hemithorax on chest X-ray at the point of admission.

Video-assisted thoracoscopic surgery: Pleural biopsy was performed under general anesthesia with selective single lung ventilation using a double lumen endotracheal tube. The patient was brought to the lateral decubitus position, the table was tilted backwards extending the distance between the ribs, and the screen was placed so that the surgeon could observe it. For a pleural biopsy, usually $10 \mathrm{~mm}$ ports, and 0 or $30^{\circ}$ optics were preferred. Pleural fluid was aspirated with a sterile 50 cc syringe, and exploration was then performed by releasing the pleural adhesions using a finger sweep before inserting the camera from the first camera port, which was placed between the midaxillary and anterior axillary line, into the seventh or eighth intercostal space. The thoracoscope was then used to access the thorax, allowing multiple biopsies to be taken from the diaphragmatic and mediastinal sides of the pleura, with the procedure terminated following bleeding control.

Pleural images acquired during VATS were classified as normal, thickening, nodule, or plaque.

Follow-up: The average follow-up period was $1919 \pm 744$ days (40-2973 days), and during the follow-up patients' whole medical records (treatment, diagnosis, comorbidities, admission to health care units) were obtained from the hospital database system, which was integrated with the Ministry of Health. In the case of lack of medical data, patients were called by phone.

Due to the retrospective nature of the study, consent was not required from the patients or their relatives. The patients with no chronic disease diagnosed during the follow-up examination and were found to be alive using the national death notification system were defined as healthy, and the biopsy results were recorded as idiopathic NSP. The final diagnosis was considered to be connective tissue disease in patients for whom rheumatologic treatments were started, and as heart failure in the patients taking cardiac medication and/or who died in the cardiology unit. Malignancy diagnoses in patients who had malignant findings in fluid cytology and flexible fiberoptic bronchoscopy (FOB) at the time of recurrent admission to the hospital were retrieved from the examination of their medical files or by phone calls to their relatives.

\section{Results}

Of the 98 patients, 78 were male (79.6\%), and 20 were female (20.4\%). Average age was $52.2 \pm 15.9$ years, a range of 21 to 87 years, and smokers made up $67 \%(n=57)$ of the patients. The most common complaints expressed were dyspnea (59\%), chest pain (56\%), and cough (39\%). Fifty-one percent of the fluid was found on the right $(n=50), 36.7 \%$ was on the left $(n=36)$, and $12.2 \%(n=12)$ was bilateral. The amount of fluid was small in $68 \%$ of the patients and large in $8 \%$. The median follow-up duration of the study was $1919 \pm 744$ days (40-2973 days) (Table I).

Table II summarizes the effusion characteristics and initial diagnostic studies of these patients. The pleural fluid LDH was in the median interquartile range (IQR), 335 [98-1430] IU/I, protein was median IQR, 48.0 [12.4-83.0] g/l, glucose was median IQR, 104 [28-267] mg/dl, ADA was median IQR, 4 [3-56] U/l, and pleural fluid appearance was serofibrinous in $81 \%$ of the patients and serohemorrhagic in $19 \%$. Prior to VATS, cytologic examination was performed once in 55.2\% and $\geq 3$ times in $11.5 \%$ of the patients and closed needle pleural biopsy in $12 \%$. Thoracic computed tomography (CT) angiography was performed in $41.8 \%$, and $\mathrm{FOB}$ in $52 \%$ of the patients. From these examinations, 77.6 percent of pleural appearance were

Table I. Clinical and radiological features of 98 patients with non-specific pleuritis

\begin{tabular}{|c|c|}
\hline \multicolumn{2}{|l|}{ Factor } \\
\hline Age [years], mean \pm SD & $52.2 \pm 15.9$ \\
\hline Sex, male/female, $n$ & $78 / 20$ \\
\hline Smoking*, yes/no, $n$ & $57 / 28$ \\
\hline \multicolumn{2}{|l|}{ Radiological characteristics (\%) } \\
\hline Right & 51.0 \\
\hline Left & 36.7 \\
\hline Bilateral & 12.2 \\
\hline Small & 68.1 \\
\hline Moderate & 23.4 \\
\hline Large & 8.5 \\
\hline Follow-up duration [days], median IQR & $\begin{array}{l}1919 \pm 744 \\
(40-2973)\end{array}$ \\
\hline
\end{tabular}


Table II. Baseline diagnostic investigations of $98 \mathrm{pa}$ tients with non-specific pleuritis

\begin{tabular}{|c|c|}
\hline Data & $n$ \\
\hline \multicolumn{2}{|l|}{ Pleural fluid } \\
\hline LDH (IU/I), median IQR & $335(98-1430)$ \\
\hline Protein (g/l), median IQR & $48.0(12.4-83.0)$ \\
\hline Glucose $(\mathrm{mg} / \mathrm{dl})$, median IQR & $104(28-267)$ \\
\hline ADA (U/I), median IQR & $14(3-56)$ \\
\hline \multicolumn{2}{|l|}{ Pleural fluid appearance (\%) } \\
\hline Serofibrinous & 81 \\
\hline Serohemorrhagic & 18 \\
\hline \multicolumn{2}{|l|}{ Predominant cells (\%) } \\
\hline Polymorphonuclear & 20.9 \\
\hline Lymphocytic & 48.8 \\
\hline Mixed & 25.6 \\
\hline Eosinophilic & 4.7 \\
\hline \multicolumn{2}{|l|}{ Pleural histology (\%) } \\
\hline 1 pleural cytology & 55.2 \\
\hline 2 pleural cytology & 33.3 \\
\hline$\geq 3$ pleural cytology & 11.5 \\
\hline Closed needle pleural biopsy & 12 \\
\hline $\begin{array}{l}\text { Chest computed tomography } \\
\text { angiography (\%) }\end{array}$ & 41.8 \\
\hline Fiberoptic bronchoscopy (\%) & 52 \\
\hline \multicolumn{2}{|c|}{ VATS visual description of parietal pleura (\%) } \\
\hline Normal & 77.6 \\
\hline Pleural thickening & 12.2 \\
\hline Pleural nodules & 8.2 \\
\hline Plaque & 2.0 \\
\hline
\end{tabular}

normal during VATS $(n=76)$, pleural thickening was found in $12.2 \%(n=12)$, and pleural nodule was detected in $8.2 \%(n=8)$.

No benign or malignant disease was detected in $70(71.4 \%)$ patients, and a specific diagnosis could be obtained in 28 patients (28.6\%). Malignancy was exhibited in 7 of 28 patients (7.1\%) (Figure 1 ).

Detailed features of patients with malignancies are set out in Table III. All patients had unilateral exudative pleural effusions, and their VATS post-biopsy pathologies were reported to be "benign". These malignancies included mesothelioma $(n=2)$, lung cancer $(n=2)$, chronic lymphocytic leukemia (CLL) $(n=1)$, soft tissue sarcoma $(n=1)$, and multiple myeloma (MM) $(n=1)$. Mesothelioma (pleural) was diagnosed after 16 months through cytological examination of the repeated pleural fluid, and the other conditions were diagnosed by peritoneal biopsy (peritoneal mesothelioma) after 12 months. One of the lung cancers was diagnosed as a non-small cell lung cancer by FOB seven years after VATS, and the other was diagnosed three years after VATS. The subtype of the tumor could not be confirmed in these patients (Figure 1). Pleural mesothelioma was detected in one of the eight patients with pleural nodules, and one of the two patients with pleural plaque subsequently developed CLL. All patients in the study with malignancies other than MM died.

Patients diagnosed with malignancies in follow-up examinations were compared with patients with a benign course (Table IV). Of the seven patients diagnosed with malignancies, two were diagnosed five and seven years after VATS. These two patients were excluded from the statistical analysis as their fluids were not associated with malignancy. Comparison of the data of the patients with a malignancy diagnosis $(n=5)$ and a benign course $(n=91)$ showed that patients with malignancies had larger amounts of fluid $(6.9 \%$ vs. $40 \%, p=0.026)$ in the chest radiographs, and more pleural plaques $(20 \%$ vs. $1.1 \%$, $p=0.020)$ and nodules ( $20 \%$ vs. $7.7 \%, p=0.020)$ in thoracoscopic images. This difference was statistically significant.

No statistically significant relationship was found between a malignancy diagnosis and age, gender, smoking status, chest pain, shortness of breath, weight loss, or pleural fluid LDH $(p>0.05)$ (Table IV).

\section{Benign diseases}

Of the 28 patients with specific diagnosis, 21 had benign diseases (21.4\%), heart failure $(n=12 ; 12.2 \%)$, connective tissue diseases $(n=3$; $3.1 \%)$, pulmonary embolism ( $n=3 ; 3.1 \%)$, and internal diseases (renal failure, liver disease) $(n=3$; $3.1 \%$ ) (Figure 1). The three patients with collagen tissue disease detected in follow-up examinations were diagnosed with rheumatoid arthritis, and of these patients, two were male, aged 41 and 62, and the other was female, aged 30 years. For all three patients, the fluid was serofibrinous and parietal pleura as a VATS finding was normal.

Computed tomography angiography was performed before VATS in two of the three patients with pulmonary embolism, with the CT angiograph of one patient with deep venous thromboembolism being deemed suboptimal because contrast agent enhancement was insufficient. Factor $\mathrm{V}$ Leiden deficiency was identified seven months 
Table III. Characteristics of patients diagnosed with malignant

\begin{tabular}{|c|c|c|c|c|c|c|c|c|c|c|}
\hline Age & Sex & $\begin{array}{l}\text { Smok- } \\
\text { ing }\end{array}$ & $\begin{array}{l}\text { Side of } \\
\text { effu- } \\
\text { sion }\end{array}$ & $\begin{array}{l}\text { Size of } \\
\text { effusion }\end{array}$ & $\begin{array}{l}\text { Pleural fluid } \\
\text { appearance }\end{array}$ & $\begin{array}{l}\text { VATS } \\
\text { visual } \\
\text { descrip- } \\
\text { tion }\end{array}$ & $\begin{array}{c}\text { Pleural } \\
\text { LDH }\end{array}$ & $\begin{array}{l}\text { Malignancy } \\
\text { type }\end{array}$ & $\begin{array}{c}\text { Time } \\
\text { from NSP } \\
\text { to cancer } \\
\text { diagnosis }\end{array}$ & Death \\
\hline 43 & M & Y & Left & Large & Serofibrinous & Normal & 356 & Lung cancer & 3 years & Y \\
\hline 37 & M & Y & Right & Small & Serofibrinous & Normal & 463 & Lung cancer & 7 years & Y \\
\hline 53 & M & Y & Right & Small & Serofibrinous & Normal & 255 & Mesothelioma* & 1 year & Y \\
\hline 52 & $\mathrm{~F}$ & $\mathrm{~N}$ & Right & Small & Serofibrinous & Nodule & 184 & Mesothelioma** & $\begin{array}{c}16 \\
\text { months }\end{array}$ & Y \\
\hline 46 & $\mathrm{~F}$ & Y & Left & Large & Serohemorrhagic & Normal & 1430 & $\begin{array}{c}\text { Soft tissue } \\
\text { sarcoma }\end{array}$ & 1 year & Y \\
\hline 74 & M & Y & Right & Small & Serofibrinous & Plaques & 417 & $\begin{array}{c}\text { Chronic } \\
\text { lymphocytic } \\
\text { leukemia }\end{array}$ & 3 years & Y \\
\hline 44 & M & Y & Left & Small & Serofibrinous & Normal & 798 & $\begin{array}{l}\text { Multiple } \\
\text { myeloma }\end{array}$ & 5 years & N \\
\hline
\end{tabular}

${ }^{\dagger}$ Large, more than half of a hemithorax on chest $X$-ray; small, less than $1 / 3$ of a hemithorax. ${ }^{*}$ Peritoneal. **Pleural. $Y-y e s, N-n o$, VATS - videoassisted thoracoscopic surgery, LDH - lactate dehydrogenase, NSP - nonspecific pleuritis.

Table IV. Baseline, investigation, and outcome characteristics of patients with nonspecific pleuritis

\begin{tabular}{|c|c|c|c|}
\hline Parameter & $\begin{array}{l}\text { Benign disease course } \\
\qquad(n=91)\end{array}$ & $\begin{array}{l}\text { False-negative result } \\
\qquad(n=5)\end{array}$ & $P^{*}$ \\
\hline Age [years] & $52.45 \pm 16.2$ & $53.6 \pm 12.1$ & 0.87 \\
\hline Male sex (\%) & 76.5 & 60 & 0.27 \\
\hline \multicolumn{4}{|l|}{ Smoking (\%) } \\
\hline Ever & 56 & 80 & \multirow[t]{2}{*}{0.51} \\
\hline Never & 30 & 20 & \\
\hline Chest pain (\%) & 57.1 & 40 & 0.45 \\
\hline Dyspnea (\%) & 59.3 & 60 & 0.97 \\
\hline Weight loss (\%) & 13.2 & 20 & 0.66 \\
\hline \multicolumn{4}{|c|}{ Effusion on chest X-ray (\%) } \\
\hline Small & 67.8 & 60 & \multirow[t]{3}{*}{0.026} \\
\hline Moderate & 25.3 & 0 & \\
\hline Large & 6.9 & 40 & \\
\hline LDH & $323(98-1269)$ & $336(184-1430)$ & 0.71 \\
\hline Total protein & $4.8 \pm 1.0$ & $4.5 \pm 0.4$ & 0.63 \\
\hline \multicolumn{4}{|c|}{ Thoracoscopy findings (\%) } \\
\hline Pleural nodules & 7.7 & 20 & \multirow[t]{4}{*}{0.020} \\
\hline Pleural plaques & 1.1 & 20 & \\
\hline Pleural thickening & 13.2 & 0 & \\
\hline Normal & 78 & 60 & \\
\hline
\end{tabular}

'Small; less than 1/3 of a hemithorax; moderate fluid, more than 1/3 but less than half of a hemithorax; large fluid, more than half of a hemithorax on chest X-ray. *Two-sided Fisher's exact test for non-parametric data; unpaired t-test for parametric data, Mann-Whitney $U$ test for non-parametric data. $P<0.05$ statistically significant. $L D H$ - lactate dehydrogenase.

after the biopsy. One of the remaining two patients had no embolism on the angiography, and the other had no angiography, with both patients subsequently developing embolisms over four months after the CT angiography.

\section{Discussion}

In this study, no specific diseases were detected in most patients with NSP (71.4\%) during longterm follow-up. Specific diagnoses were made in 
28 patients $(28.6 \%)$, and most of these consisted of benign diseases, such as pulmonary embolism and connective tissue diseases, particularly heart failure. Malignant diseases were noted in seven patients, two of these patients having mesothelioma, the others having non-mesothelioma disease, with most of the malignancies being detected within 36 months. Patients with effusions involving more than half of a hemithorax, pleural plaque, and nodule in the thoracoscopic image were noted to be more likely to have a malignancy.

Exudative pleural effusions were diagnosed as NSP in $5-31 \%$ of cases despite performing all invasive diagnostic procedures including thoracoscopy [12-14]. In our cohort, this rate was found to be $23 \%$. This may be due to the extended biopsy indications and shorter follow-up period. Making the decision of biopsy after the establishment and evaluation of a joint council with thoracic surgery of these patients may contribute to a lower rate.

Studies have shown that $85 \%$ of the patients with NSP had a benign course over an average of 6 to 62 months of follow-up [11,14-17], and malignancy was observed in 3.3 to $25.5 \%$ of the cases during the follow-up of patients diagnosed with NSP after various biopsy techniques [15-18]. This large range is likely due to the different diagnostic criteria applied by investigators. The most reported malignant diagnosis was malignant mesothelioma [14, 15, 19]; however, other malignancies such as metastatic cancers, lung cancer, and lymphoma were also reported, albeit less frequently [12, 17-19].

Mesothelioma has been reported to show regional differences in some studies due to asbestos exposure, with the incidence of mesothelioma reported in the UK, Turkey and Egypt from the follow-up of NSP patients in high-risk areas being $12,15.8$ and $27.3 \%$, respectively $[16,19,20]$. This rate is higher compared to studies in the USA and Korea, where the risk of mesothelioma is reported to be low $(0-7.8 \%)[21,22]$. However, there are studies reporting that most of these malignancies were caused by mesothelioma, even in patients with a low risk of mesothelioma $[15,17]$.

For patients diagnosed with malignancy in post-NSP follow-up, it was reported that the pathology of "non-specific pleuritis" gave a false negative result, and this negativity was the most common in mesothelioma [13, 17, 23]. Researchers investigating the factors that caused this result found that, for example, although the pleural nodule was a typical manifestation of malignant mesothelioma, the pleura could appear completely normal [24]. In malignant mesothelioma, the fact that neoplastic invasion was submesothelial, and the pleura was of normal appearance, may have caused difficulties in determining the area where the thoracoscopist would perform a biopsy [25]. In addition, as the disease was initially paucicellular, showing focal involvement, the pleura being obstructed by multiple adhesions, or technically inadequate biopsy due to the presence of intense fibrosis, this may have given rise to other causes of false negativity $[11,24]$. Jansen et al. reported that thoracoscopy results were negative in seven of ten patients diagnosed with mesothelioma due to the fibrin layer in the pleura [13].

In our study, similar to the literature, $7 \%$ of patients had malignancy, the most common of which was mesothelioma (2\%) and lung cancer (2\%). Other malignancies included MM, CLL, and soft tissue sarcoma, with one patient for each of these malignancies. In our cohort, nodules were detected in the pleura of the patients with pleural mesothelioma, while pleura was of normal appearance in peritoneal mesothelioma. In the last patient, pleural fluid could have developed by trans-diaphragmatic transition as a reaction to peritoneal disease, explaining why the pleura appeared normal in that case.

It is reported that the pleural effusion seen in $M M$ is due to the accompanying diseases rather than the underlying primary disease (less than 1\%) [26]. The patient with MM in our cohort had hypertension and heart failure as additional diagnoses. It is believed that the pleural effusion of the patient diagnosed with MM five years after VATS biopsy, and who is still alive, was not due to the primary disease.

In pleural biopsies of patients with CLL, where it can be difficult to differentiate malignant lymphocytes from reactive normal lymphocytes, if there is clinical suspicion, the diagnosis can be made by performing further genetic or immunogenetic tests [27]. In soft tissue sarcomas, pleural effusion has been found to occur before primary malignancy. The diagnosis of sarcoma is reported to be difficult in these patients because the characteristic morphological findings could be lost in the pleural fluid [28]. In our study, the diagnosis of sarcoma and CLL was made one and three years after the NSP diagnosis, respectively, and it was learned that each patient died shortly after the diagnosis.

Although it states in the British Thoracic Society Guideline for pleural diseases that it may be appropriate to apply a "wait-and-see" approach in patients with NSP, it is unclear how long this period should be [1,29], as there are different results regarding the time from thoracoscopic biopsy to the final diagnosis of malignancy in the follow-up of patients with NSP. According to a large number of studies, malignancy was detected in the time interval ranging from two months to three years after biopsy [12, 14-16]. Among the malignancies, mesothelioma appeared in the first year after 
Table V. Comparison of data from this study with other published results

\begin{tabular}{|c|c|c|c|c|c|c|c|}
\hline Author (ref.) & $\begin{array}{c}\text { Country, } \\
\text { year }\end{array}$ & $\begin{array}{c}\text { Patients } \\
\text { with NSP } \\
(n)\end{array}$ & $\begin{array}{c}\text { No. of } \\
\text { malignancies } \\
\text { during } \\
\text { follow-up }\end{array}$ & $\begin{array}{l}\text { Mesothelioma } \\
\text { (n) }\end{array}$ & $\begin{array}{l}\text { Other } \\
\text { malign } \\
(n)\end{array}$ & $\begin{array}{l}\text { Author's } \\
\text { recommendation }\end{array}$ & $\begin{array}{l}\text { Follow- } \\
\text { up } \\
\text { period }\end{array}$ \\
\hline Janssen [13] & $\begin{array}{l}\text { The } \\
\text { Netherlands, } \\
2004\end{array}$ & 208 & 31 (15\%) & 10 & 21 & $\begin{array}{c}\text { Asbestos } \\
\text { exposure, } \\
\text { suspicion } \\
\text { of malignancy } \\
\text { in CT }\end{array}$ & $\begin{array}{c}2 \\
\text { years }\end{array}$ \\
\hline $\begin{array}{l}\text { Venekamp } \\
\text { [23] }\end{array}$ & $\begin{array}{l}\text { Belgium, } \\
2005\end{array}$ & 60 & $5(8 \%)$ & 2 & 3 & $\begin{array}{l}\text { Asbestos } \\
\text { exposure, } \\
\text { recurrent fluid }\end{array}$ & $\begin{array}{c}3 \\
\text { years }\end{array}$ \\
\hline Davies [18] & $\begin{array}{l}\text { Oxford, } \\
2010\end{array}$ & 44 & $5(12 \%)$ & 5 & 5 & $\begin{array}{c}\text { Clinical evaluation } \\
\text { on case-by-case } \\
\text { basis }\end{array}$ & $\begin{array}{c}21 \\
\text { months }\end{array}$ \\
\hline $\begin{array}{l}\text { Metintas } \\
{[19]}\end{array}$ & $\begin{array}{l}\text { Turkey, } \\
2012\end{array}$ & 101 & 19 (15.8\%) & 16 & 3 & $\begin{array}{l}\text { CT findings, } \\
\text { thoracoscopist's } \\
\text { impression, } \\
\text { chest pain, } \\
\text { female gender in } \\
\text { asbestos exposure }\end{array}$ & $\begin{array}{c}2 \\
\text { years }\end{array}$ \\
\hline DePew [15] & $\begin{array}{l}\text { Minnesota, } \\
2014\end{array}$ & 86 & $3(3.5 \%)$ & 3 & - & $\begin{array}{l}\text { Asbestos, } \\
\text { chest pain }\end{array}$ & $\begin{array}{c}5 \\
\text { years }\end{array}$ \\
\hline Yang [12] & $\begin{array}{l}\text { China, } \\
2017\end{array}$ & 52 & $8(15 \%)$ & 5 & 3 & $\begin{array}{l}\text { Chest pain, } \\
\text { pleural plaques, } \\
\text { pleural nodules, } \\
\text { recurrent fluid }\end{array}$ & $\begin{array}{c}35 \\
\text { months }\end{array}$ \\
\hline $\begin{array}{l}\text { Gunluoglu } \\
\text { [30] }\end{array}$ & $\begin{array}{l}\text { Turkey, } \\
2014\end{array}$ & 53 & $2(3.7 \%)$ & 2 & - & $\begin{array}{l}\text { Large fluid, } \\
\text { recurrent fluid, } \\
\text { age, weight loss }\end{array}$ & $\begin{array}{c}24 \\
\text { months }\end{array}$ \\
\hline Ferrer [16] & $\begin{array}{l}\text { Spain, } \\
1996\end{array}$ & 40 & $2(5 \%)$ & 1 & 1 & $\begin{array}{l}\text { Thick pleura, } \\
\text { recurrent fluid }\end{array}$ & $\begin{array}{c}62 \\
\text { months }\end{array}$ \\
\hline Ryan [17] & $\begin{array}{l}\text { US, } \\
1981\end{array}$ & 51 & $13(25.5 \%)$ & 4 & 9 & - & - \\
\hline $\begin{array}{l}\text { Present } \\
\text { study }\end{array}$ & 2020 & 98 & 7 (7.1\%) & 2 & 5 & $\begin{array}{l}\text { Large liquid, } \\
\text { pleural plate, } \\
\text { nodule, } \\
\text { non-mesothelioma } \\
\text { malignancies }\end{array}$ & $\begin{array}{c}5 \\
\text { years }\end{array}$ \\
\hline
\end{tabular}

NSP - nonspecific pleuritis, CT - computed tomography.

biopsy in most of the studies [12-15]. In the literature, the longest time between NSP and mesothelioma diagnosis was reported in the studies of Davies et al. and Ferrer et al. as 39 months and 4 years $[14,16]$; the authors concluded by suggesting that the follow-up period should be two years at most despite the possibility of malignancy in NSP patients [11]. In our study, five patients with malignancies were diagnosed in the first three years, while the remaining two patients were diagnosed after three years.

In certain studies, particular risk factors were analyzed in patients with malignancy after NSP, and close clinical and radiological follow-up was recommended in this limited number of patients, although the recommendation did not cover every patient. Among these factors, persistent pain, re- current effusions, massive effusion, hemorrhagic fluid, > $1 \mathrm{~cm}$ thickening on $\mathrm{CT}$, pleural nodules, plaques, and thickening as thoracoscopic appearances were most commonly reported $[12,13,15,16$, $19,23,30]$. On the other hand, contrary to these results, Davies et al. showed that fluid features and thoracoscopic images were not necessarily meaningful in determining malignancy and emphasized that each patient should be evaluated on a case-by-case basis [14]. Table $V$ summarizes the study results of different authors, and some of the recommendations for the follow-up of NSP patients. In our study, no significant relationship could be found between patients diagnosed with malignancy after NSP and age, gender, smoking, or LDH value of pleural fluid. However, it was observed that malignancy was more common in pa- 
tients with NSP who had a large amount of fluid, and had a nodule and plaque found in thoracoscopic imaging.

In the studies, benign diseases were reported in 25 to $45 \%$ of NSP patients during their long-term follow-up [12, 15]. The most frequently reported diseases were heart failure, parapneumonic, tuberculosis, collagen tissue diseases, pulmonary embolism, and benign asbestos-related fluid [12, $16,21,30]$. Consistent with the literature, the frequency of benign diseases in our cohort was $21.4 \%$, the most common of which was heart failure $(21 \%)$, followed by rheumatic disease (3\%), and pulmonary embolism (3\%). All these conditions could have caused pleural effusion. Pleural histopathology due to benign diseases did not show any characteristic specific to the underlying disease except for tuberculosis [31, 32]. Therefore, we could not expect VATS biopsy specimens of these patients to be fully diagnostic. Studies have shown that pleural effusion can occur in heart failure and rheumatological diseases without primary disease symptoms as well [16, 21, 33]. Pulmonary embolism was observed in 1.6 to $3.8 \%$ of patients with NSP $[12,21,23]$, and interestingly, no embolism was observed in the preoperative embolism tests of these patients either in our study or in other studies.

In our study, the cause of effusion was not identifiable in the long-term follow-up of most of the patients diagnosed with NSP (71\%). This rate is between 25 and $80 \%$ in other studies $[12,14-16,30]$. It is thought that many factors can contribute to this condition, defined as idiopathic pleuritis, consisting of viral and mycoplasma pneumonias, which are difficult to prove, and asbestos exposure or collagen tissue diseases [34]. Environmental asbestos exposure in our country represents a significant proportion of cases in certain regions, and our hospital is a center to which patients are referred from different regions of the country. Therefore, we believe that some of the NSP cases with a benign course may be caused by asbestos exposure [19]. However, as per the limitations of the study, environmental or occupational asbestos exposure histories were unavailable for the majority of patients.

The key limitation of the study is that it was retrospective, single-centered, and adequate information about asbestos exposure was not available from patients' medical records. A further limitation was that the symptoms experienced by the patients following VATS were not fully documented.

In conclusion, the majority of NSPs do not appear to have an underlying disease, and the vast majority have a benign course. These patients are at risk, though minimally, of malignancy. Mesothelioma and other malignancies can be exhibited within the first 36 months after biopsy, with fluid in more than half of a hemithorax possibly being the determining factor for pleural nodule and plaque malignancy from thoracoscopic images. Therefore, closer monitoring of these patients is recommended.

\section{Conflict of interest}

The authors declare no conflict of interest.

\section{References}

1. Hooper C, Lee YC, Maskell N. Investigation of a unilateral pleural effusion in adults: British Thoracic Society Pleural Disease Guideline 2010. Thorax 2010; 65: ii4-17.

2. Light RW, Lee YCG (eds.). Textbook of Pleural Diseases. Boca Raton: CRC Press, Taylor and Francis Group; 2016.

3. Fishman AP, Elias JA, Fishman JA, Grippi MA, Senlor RM, Pack Al (eds.). Fishman's Pulmonary Diseases and Disorders. New York: Mc Graw-Hill Education; 2008.

4. Light RW, Rogers JT, Moyers JP, et al. Prevalence and clinical course of pleural effusions at 30 days after coronary artery and cardiac surgery. Am J Respir Crit Care Med 2002; 166: 1567-71.

5. Maskell NA. Undiagnosed pleural effusions. In: Light RW, Gary Lee YC (eds.). Textbook of Pleural Diseases. $2^{\text {th }}$ ed. London: CRC Press, Taylor and Francis Group; 2008, pp. 491-8.

6. Boutin C, Viallat JR, Cargnino P, Farisse P. Thoracoscopy in malignant pleural effusions. Am Rev Resp Dis 1981; 124: 588-92.

7. Shojaee S, Lee HJ. Thoracoscopy: medical versus surgical - in the management of pleural diseases. J Thorac Dis 2015; 7: 339-51.

8. Medford AR, Awan YM, Marchbank A, Rahamim J, Unsworth-White J, Pearson PJ. Diagnostic and therapeutic performance of video-assisted thoracoscopic surgery (VATS) in investigation and management of pleural exudates. Ann R Coll Surg Engl 2008; 90: 597-600.

9. Hazelrigg SR, Nunchuck SK, LoCicero J 3rd. Video assisted thoracic surgery study group data. Ann Thorac Surg 1993; 56: 1039-43.

10. Salm SA. The pleura. Am Rev Respir Dis 1988; 138: 184-234.

11. Janssen J, Maldonado F, Metintas M. What is the significance of non-specific pleuritis? A trick question. Clin Respir J 2018; 12: 2407-10.

12. Yang T, Wu YB, Wang Z, et al. Long-term outcome of patients with nonspecific pleurisy at medical thoracoscopy. Respir Med 2017; 124: 1-5.

13. Janssen JP, Ramlal S, Mravunac M. The long-term followup of exudative pleural effusion after nondiagnostic thoracoscopy. J Bronchol 2004; 11: 169-74.

14. Davies HE, Nicholson JE, Rahman NM, Wilkinson EM, Davies RJ, Lee YC. Outcome of patients with nonspecific pleuritis/fibrosis on thoracoscopic pleural biopsies. Eur J Cardiothorac Surg 2010; 38: 472-7.

15. DePew ZS, Verma A, Wigle D, Mullon JJ, Nichols FC, Maldonado F. Nonspecific pleuritis: optimal duration of follow-up. Ann Thorac Surg 2014; 97: 1867-71.

16. Ferrer JS, Muñoz XG, Orriols RM, Light RW, Morell FB. Evolution of idio-pathic pleural effusion: a prospective, long-term follow-up study. Chest 1996; 109: 1508-13.

17. Ryan CJ, Rodgers RF, Unni KK, Hepper NG. The outcome of patients with pleural effusion of indeterminate cause at thoracotomy. Mayo Clin Proc 1981; 56: 145-49. 
18. Karpathiou G, Anevlavis S, Tiffet O, et al. Clinical longterm outcome of non-specific pleuritis (NSP) after surgical or medical thoracoscopy. J Thorac Dis 2020; 12: 2096-104.

19. Metintas M, Ak G, Cadirci O, Yildirim H, Dundar E, Metintas S. Outcome of patients with fibrinous pleuritis after medical thoracoscopy. Respir Med 2012; 106: 1177-83.

20. Akl Y, Kaddah S, Abdelhafeez A, Salah R, Lotayef M. Epidemiology of mesothelioma in Egypt. A ten-year (19982007) multicentre study. Arch Med Sci 2010; 6: 926-31.

21. Leslie WK, Kinasewitz CT. Clinical characteristics of the patients with nonspecific pleuritis. Chest 1988; 94:603-8.

22. Kim NJ, Hong SC, Kim JO, Suhr JW, Kim SY, Ro HK. Etiologic considerations of nonspecific pleuritis. Korean J Intern Med 1991; 6: 58-63.

23. Venekamp LN, Velkeniers B, Noppen M. Does 'idiopathic pleuritis' exist? Natural history of non-specific pleuritis diagnosed after thoracoscopy. Respiration 2005; 72: 74-8.

24. Cagle PT, Allen TC. Pathology of the pleura: what the pulmonologists need toknow. Respirology 2011; 16: 430-8.

25. Al-Izzi M, Thurlow NP, Corrin B. Pleural mesothelioma of connective tissue type, localized fibrous tumour of the pleura, and reactive submesothelial hyperplasia. An immunohistochemical comparison. J Pathol 1989; 158:41-4.

26. Coppola A, Ghinassi G, Ciarleglio G, et al. Pleural effusion as first extra-medullary clinical presentation of an occult multiple myeloma: the role of medical thoracoscopy. Respir Med Case Rep 2020; 29: 101013.

27. Ahmed S, Siddiqui AK, Rossoff L, Sison CP, Rai KR. Pulmonary complications in chronic lymphocytic leukemia. Cancer 2003; 98: 1912-7.

28. Chen AL, Janko E, Pitman MB, Chebib I. Clinical, cytologic, and immunohistochemical features of sarcomas involving body cavity fluids. Cancer Cytopathol 2019; 127: 778-84.

29. Maskell NA, Butland RJ. BTS guidelines for the investigation of a unilateral pleural effusion in adults. Thorax 2003; 58: ii8-17.

30. Gunluoglu G, Olcmen A, Gunluoglu MZ, et al. Long-term outcome of patients with undiagnosed pleural effusion. Arch Bronconeumol 2015; 51: 632-6.

31. Janssen JP. Why you do or do not need thoracoscopy. Eur Respir Rev 2010; 19: 213-6.

32. Wrightson JM, Davies HE. Outcome of patients with nonspecific pleuritis at thoracoscopy. Curr Opin Pulm Med 2011; 17: 242-6.

33. Shaw M, Collins BF, Ho LA, Raghu G. Rheumatoid arthritisassociated lung disease. Eur Respir Rev 2015; 24: 1-16.

34. Gaensler EA. 'Idiopathic' pleural effusion. N Engl J Med 1970; 283: 816-7. 